\title{
EFFECT OF SUPPORT MATERIALS ON CATALYTIC ACTIVITY OF NANO RUTHENIUM CATALYST IN HYDROGENOLYSIS OF GLYCEROL
}

\section{(Kesan Bahan Penyokong Terhadap Aktiviti Pemangkin Nano Ruthenium dalam Hidrogenolisis Gliserol)}

\author{
Noraini Hamzah ${ }^{1} *$ and Mohd Ambar Yarmo ${ }^{2}$ \\ ${ }^{1}$ School of Chemistry and Environmental, Faculty of Science and Technology \\ Universiti Teknologi MARA, 40450 Shah Alam, Selangor, Malaysia \\ ${ }^{2}$ School of Chemical Sciences and Food Technology, Faculty of Science and Technology, \\ Universiti Kebangsaan Malaysia, 43600 UKM Bangi, Selangor, Malaysia
}

*Corresponding author: pnoraini@salam.uitm.edu.my

Received: 24 February 2015; Accepted: 27 October 2015

\begin{abstract}
A series of heterogenous catalysts based on supported ruthenium were prepared from $\mathrm{RuCl}_{3}$ precusor by impregnation method. The effect of support materials (bentonite, $\mathrm{TiO}_{2}, \mathrm{Al}_{2} \mathrm{O}_{3}$ and $\mathrm{SiO}_{2}$ ) on catalytic activity of $\mathrm{Ru}$ catalyst for hydrogenolysis of glycerol were investigated under mild reaction condition of $150^{\circ} \mathrm{C}$ and 20 bar initial hydrogen pressure for 7 hours reaction time and glycerol concentration was $20 \%$ (wt). It was found that the type of support material have significant effects on the activity and selectivity of glycerol hydrogenolysis. The order of Ru catalyst activity was $\mathrm{Ru} /$ bentonite $>\mathrm{Ru} / \mathrm{Al}_{2} \mathrm{O}_{3} \approx \mathrm{Ru} / \mathrm{TiO} \mathrm{O}_{2}>\mathrm{Ru} / \mathrm{SiO}{ }_{2}$. This study showed that bentonite supported Ru catalyst was the most active with glycerol conversion reaching $62.5 \%$ compared to other supports. All the tested catalyst exhibited high selectivity to 1,2-propanediol with more than $80 \%$. Characterization of the catalysts was carried out using BET, XPS, FESEM-EDX and TEM to obtain the physicochemical properties of the catalysts.
\end{abstract}

Keywords: hydrogenolysis, ruthenium, bentonite, 1,2-propanediol, glycerol

Satu siri pemangkin heterogen berasaskan logam ruthenium berpenyokong disediakan daripada prekusor garam $\mathrm{RuCl}_{3}$ menggunakan teknik impregnasi. Kesan bahan penyokong (bentonit, $\mathrm{TiO}_{2}, \mathrm{Al}_{2} \mathrm{O}_{3}$ dan $\mathrm{SiO}_{2}$ ) terhadap aktiviti pemangkin $\mathrm{Ru}$ dalam hidrogenolisis gliserol dilakukan pada keadaan tindak balas yang sederhana dengan suhu $150^{\circ} \mathrm{C}$, tekanan awal hydrogen 20 bar, masa tindak balas 7 jam dan kepekatan gliserol 20\%(wt). Keputusan yang diperolehi menunjukkan jenis bahan penyokong mempunyai kesan signifikan terhadap aktiviti dan pemilihan dalam hidrogenolisi gliserol. Turutan aktiviti pemangkin $\mathrm{Ru}$ adalah $\mathrm{Ru}$ /bentonit $>\mathrm{Ru} / \mathrm{Al}_{2} \mathrm{O}_{3} \approx \mathrm{Ru} / \mathrm{TiO}_{2}>\mathrm{Ru} / \mathrm{SiO}_{2}$. Kajian ini menunjukkan pemangkin $\mathrm{Ru}$ yang disokong atas bentonit adalah pemangkin yang paling aktif dengan peratus penukaran mencapai $62.5 \%$ berbanding dengan penyokong lain. Semua pemangkin yang diuji menunjukkan peratus pemilihan terhadap produk 1,2-propandiol yang tinggi iaitu melebihi $80 \%$. Pencirian pemangkin dilakukan menggunakan alat BET, XPS, FESEM-EDX dan TEM bagi mendapatkan sifat-sifat fizikokimia pemangkin.

Kata kunci: hidrogenolisis, ruthenium, bentonit, 1,2-propanediol, gliserol

\section{Introduction}

Glycerol, one of the renewable resources, is obtained as a by-product in hydrolysis of fat, soap-manufacturing process and production of biodiesel [1]. Production of every $9 \mathrm{~kg}$ biodiesel, about $1 \mathrm{~kg}$ of crude glycerol by-product 
is formed [2]. Nowadays, biodiesel derived from vegetable oils and animal fats has received considerable attention. The recent rapid development of biodiesel processes has caused some concern over the oversupply of glycerol in the glycerol market. The glycerol market will likely to be saturated because of limited utilization of glycerol at the present time. It is known that glycerol can be catalytically converted into functionalized and value-added chemical via a variety of reaction routes such as oxidation, hydrogenolysis, dehydration, pyrolysis, steam reforming, etherification, esterification, oligomerization and polymerization [3]. The hydrogenolysis of glycerol produces 1,2propanediol (1,2-PDO) and ethylene glycol (EG) as a major products with a $4 \%$ annual market growth [4]. Typical uses of 1,2-propanediol are in unsaturated polyester resins, functional fluids, pharmaceuticals, cosmetics, paints and others [5]. Process that can efficiently convert glycerol to a useful compound would be important as an economical and sustainable process. Conversion of glycerol using supported catalyst has been extensively studied by several groups [6-9]. In published papers the effect of various supports $\left(\mathrm{TiO}_{2}, \mathrm{SiO}_{2}, \mathrm{NaY}, \gamma-\mathrm{Al}_{2} \mathrm{O}_{3}\right.$ and active -carbon) on $\mathrm{Ru}$ catalysts were investigated and found that the support material can influence the metal particles size.

Most of the previous studies have employed solid acid like carbon [2], alumina [10] and silica [8, 11] to be used for supporting the metal catalyst. Bentonite which has surface area about $100 \mathrm{~m}^{2} / \mathrm{g}$ is natural clay raw material that has high content of montmorillonite and less amounts of other clay minerals. Previous report have shows that bentonite can be used as support material in catalytic reaction.[12,13] They found that Ru-Cu bimetallic catalysts supported on clay exhibited $100 \%$ of glycerol conversion and $85 \%$ yield of 1,2-propanediol at $230^{\circ} \mathrm{C}$ and $8 \mathrm{MPa}$. Previous study by Yuan et al. claimed that solid base (hydrotalcite and $\mathrm{MgO}$ ) supported $\mathrm{Pt}$ catalysts exhibited the predominant activity and higher 1,2-PDO selectivity than that of solid acids $\left(\mathrm{Al}_{2} \mathrm{O}_{3}, \mathrm{H}-\mathrm{ZSM} 5\right.$ and H-Beta)[14].

Since there are only a few studies focus on the application of solid base supported metal catalyst in hydrogenolysis of glycerol, therefore we want to report an efficient solid-base supported Ru catalyst for glycerol hydrogenolysis to 1,2-PDO. In this work, the effect of other support materials $\left(\mathrm{Al}_{2} \mathrm{O}_{3}, \mathrm{SiO}_{2}\right.$ and $\left.\mathrm{TiO}_{2}\right)$ with bentonite material on catalytic performance of ruthenium $(\mathrm{Ru})$ based catalysts in the hydrogenolysis glycerol were investigated. The scope of this study was to investigate the effect of support materials on the structure and physicochemical characteristics of the catalyst as well as the catalytic performance in the glycerol hydrogenolysis reaction.

\section{Chemicals}

\section{Materials and Methods}

Ruthenium chloride hydrate, $\mathrm{RuCl}_{3} \cdot \mathrm{H}_{2} \mathrm{O}$ used as a metal precursor was purchased from Sigma. Aldrich. $\mathrm{TiO}_{2}, \mathrm{SiO}_{2}$ and $\mathrm{Al}_{2} \mathrm{O}_{3}$ used as support were purchased from Sigma, Aldrich. The clay mineral used in this work is a calciumrich bentonite $(\mathrm{CaB})$ was obtained as powder from PT Superintending Company of Indonesia also used as support.

\section{Catalyst preparation}

All the supports were calcined in air at $500{ }^{\circ} \mathrm{C}$ for 3 hours before used to remove moisture and impurities. About 0.09 gram of $\mathrm{RuCl}_{3}$ was dissolved in acetone and stirred for 15 minutes. Then, approximately $1.8 \mathrm{~g}$ of support was added into the resulting solution and sonicated for 1 hour. After that, the mixture was dried in oven at $60{ }^{\circ} \mathrm{C}$ overnight. The supported catalyst was calcined in $\mathrm{N}_{2}$ flow $(10 \mathrm{ml} / \mathrm{min})$ at $300{ }^{\circ} \mathrm{C}$ for 2 hours and then reduced in $\mathrm{H}_{2}$ flow $(10 \mathrm{ml} / \mathrm{min})$ at $200{ }^{\circ} \mathrm{C}$ for 2 hours.

\section{Catalyst characterization}

The X-ray photoelectron spectrum (XPS) data of the as-prepared samples were obtained by XPS Ultra from Kratos, UK using $300 \mathrm{~W} \operatorname{MgK} \alpha$ radiation. The base pressure was about $3 \times 10^{-9} \mathrm{mbar}$. The binding energies were referenced for the $\mathrm{C} 1 \mathrm{~s}$ line at $284.5 \mathrm{eV}$ from adventitious carbon. Transmission electron microscope (TEM) images were taken for determination of the particle size with a CM12 instrument (Philips) operated at $200 \mathrm{kV}$. General morphology information of the samples was examined by FESEM with LEO 1450VP model equipped with energy dispersive X-ray detector (EDX). All the samples were scanning in a high-vacuum mode at $20 \mathrm{kV}$.

\section{Catalytic reaction}

The catalytic hydrogenolysis reactions were carried out in a $50 \mathrm{ml}$ stainless-steel autoclave, PARR reactor equipped with an electronic temperature controller and a mechanical stirrer. Reaction was normally conducted under the following standard conditions: $150^{\circ} \mathrm{C}$ temperature, 20 bar initial hydrogen pressure, $1.0 \mathrm{~g}$ catalyst weight, $23 \mathrm{ml}$ of 
$20 \%(\mathrm{wt})$ aqueous solution of glycerol, $7 \mathrm{~h}$ reaction time and at constant stirring speed. Before reaction started, the reactor was flushed three times with $\mathrm{N}_{2}$ in order to remove oxygen gas and pressurized with $\mathrm{H}_{2}$ to 20 bar.

\section{Results and Discussion}

The physical properties of prepared catalysts by BET nitrogen adsorption isotherm are presented in Table 1 . The trend shows that BET surface area of supported catalyst increased following this order: $\mathrm{Ru} / \mathrm{TiO}_{2}<\mathrm{Ru} / \mathrm{bentonite}<$ $\mathrm{Ru} / \mathrm{SiO}_{2}<\mathrm{Ru} / \mathrm{Al}_{2} \mathrm{O}_{3}$. BET analysis revealed that BET surface area of $\mathrm{Ru} /$ bentonite was decreased drastically. It seems that about $65.8 \%$ of Ru particle was loaded into the mesoporous of bentonite. This result indicates that pore volume of bentonite was large and much Ru particle could load into pore of bentonite.

The isotherm plot revealed that the catalysts studied exhibited a very much similar types of isotherms, having a mixture of Type III and Type IV (Table 2). The isotherm plot displayed a hysteresis loop which is of the Type H2 according to the IUPAC classification. Type $\mathrm{H} 2$ indicating the presence of non-uniformed cylindrical pores.

Table 1. Surface area of supports and supported catalyst

\begin{tabular}{lccc}
\hline Support & $\begin{array}{c}\text { BET Surface Area } \\
\left(\mathbf{m}^{2} / \mathbf{g}\right)\end{array}$ & Supported Catalysts & $\begin{array}{c}\text { BET Surface Area } \\
\left(\mathbf{m}^{2} / \mathbf{g}\right)\end{array}$ \\
\hline Bentonite & 101.3 & $\mathrm{Ru} /$ bentonite & 35.4 \\
$\mathrm{TiO}_{2}$ & 8.8 & $\mathrm{Ru} / \mathrm{TiO}_{2}$ & 7.9 \\
$\mathrm{SiO}_{2}$ & 130.5 & $\mathrm{Ru} / \mathrm{SiO}_{2}$ & 125.3 \\
$\mathrm{AlO}_{3}$ & 155.6 & $\mathrm{Ru} / \mathrm{Al}_{2} \mathrm{O}_{3}$ & 141.4 \\
\hline
\end{tabular}

Table 2. Types of isotherms, porosity, hysteresis and shape of pore for catalysts studied

\begin{tabular}{lcccc}
\hline Catalysts & $\begin{array}{c}\text { Type of } \\
\text { isotherms }\end{array}$ & Types of pores & $\begin{array}{c}\text { Types of } \\
\text { hysteresis }\end{array}$ & Shape of Pore \\
\hline $\mathrm{Ru} / \mathrm{bentonite}$ & $\mathrm{IV}$ & Mesopore & $\mathrm{H} 2$ & Non uniform cylindrical pore \\
$\mathrm{Ru} / \mathrm{TiO}_{2}$ & $\mathrm{IV}$ & Mesopore & $\mathrm{H} 4$ & Uniform slit shape \\
$\mathrm{Ru} / \mathrm{SiO}_{2}$ & $\mathrm{IV}$ & $\begin{array}{c}\text { Mesopore } \\
\text { Mesopore and } \\
\text { macropore }\end{array}$ & $\mathrm{H} 4$ & Uniform slit shape \\
$\mathrm{Ru} / \mathrm{Al}_{2} \mathrm{O}_{3}$ & III and IV & $\mathrm{H}$ & Non-uniform slit shape \\
\hline
\end{tabular}

Since XRD analysis did not show any peak related to Ru species except Ru/bentonite, therefore in order to investigate the presence of Ru species on the support, EDX analysis was done. Figure 1 clearly shows the existence of $\mathrm{Ru}$ species on the support.

The presence of Ru species was also indicated in the XPS wide scan and the binding energy (B.E) as shown in Table 3. The B.E of 280 and $283 \mathrm{eV}$ is related to the chemical states of $\mathrm{Ru}^{0}$ and $\mathrm{Ru}^{\mathrm{n}+}$ respectively [15]. 

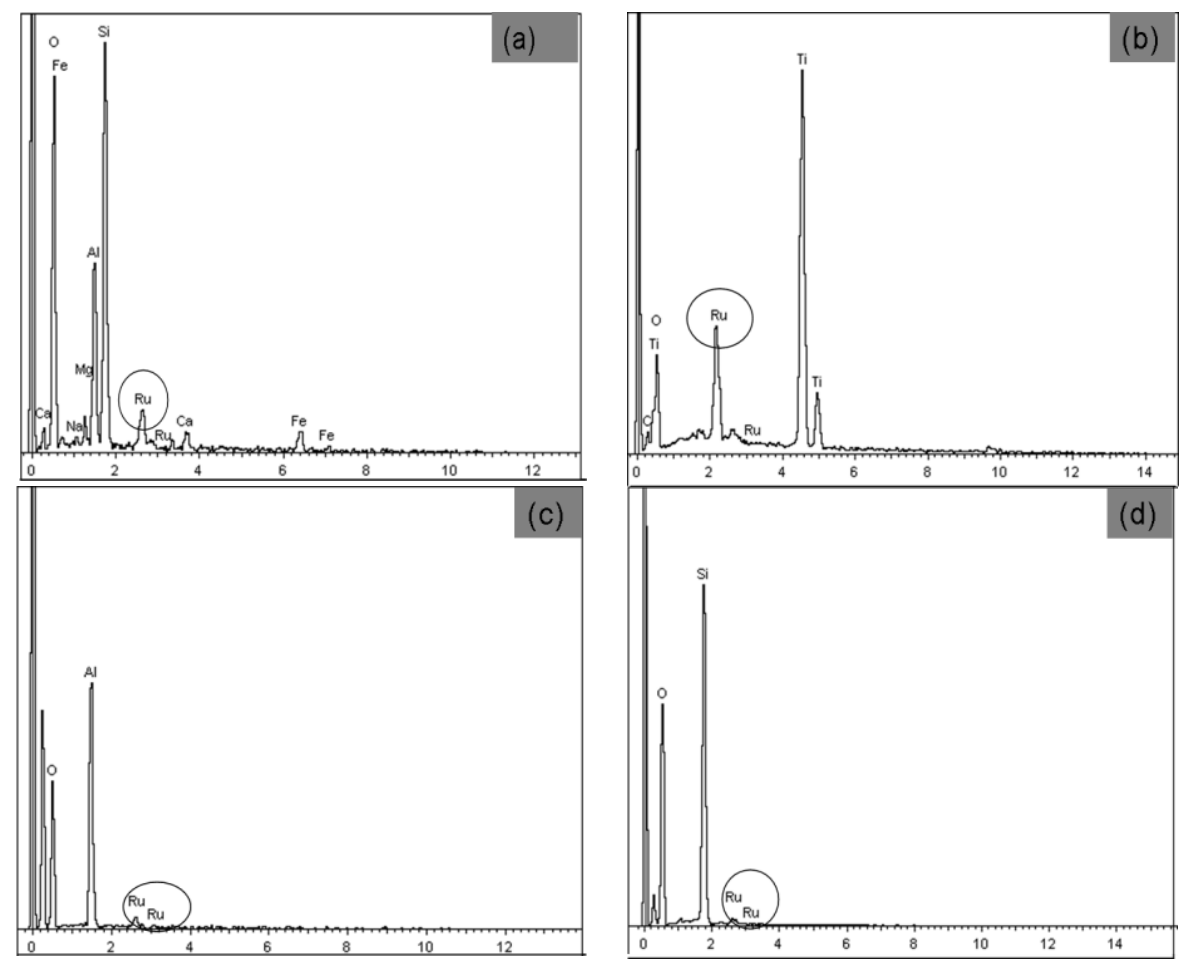

Figure 1. Analysis EDX spectrum of (a) Ru/bentonite, (b) $\mathrm{Ru} / \mathrm{TiO}_{2}$, (c) $\mathrm{Ru} / \mathrm{Al}_{2} \mathrm{O}_{3}$ and (d) $\mathrm{Ru} / \mathrm{SiO}_{2}$

Table 3. XPS data for the supported catalyst

\begin{tabular}{lccc}
\hline \multirow{2}{*}{ Supported catalyst } & \multicolumn{3}{c}{ Binding energy (eV) } \\
\cline { 2 - 4 } & $\mathbf{C ~ 1 s}$ & $\mathbf{R u ~ 3 d} \mathbf{d}_{\mathbf{5} / \mathbf{2}}$ & $\mathbf{R u ~ 3 d}_{\mathbf{3} \mathbf{2}}$ \\
\hline $\mathrm{Ru} /$ bentonite & 284.8 & 282.0 & - \\
$\mathrm{Ru} / \mathrm{TiO}_{2}$ & 284.8 & 281.0 & 283.3 \\
$\mathrm{Ru} / \mathrm{SiO}_{2}$ & 284.8 & 281.5 & 283.4 \\
$\mathrm{Ru} / \mathrm{Al}_{2} \mathrm{O}_{3}$ & 284.8 & 281.7 & 283.5 \\
\hline
\end{tabular}

Chemical state of the Ru element was investigated via narrow scan and the spectra are shown in Figure 2. Since the binding energy (B.E) of $\mathrm{Ru} 3 \mathrm{~d}_{5 / 2}(\approx 280 \mathrm{eV})$ overlapped with that $\mathrm{C} 1 \mathrm{~s}(\approx 284.5 \mathrm{eV})$, it was difficult to resolve the small $\mathrm{Ru}$ peak out from the large peak of $\mathrm{C} 1 \mathrm{~s}$. The $\mathrm{Ru} 3 \mathrm{~d}$ spectra revealed the presence of two different chemical states on the surface $\left(\mathrm{Ru}^{0}\right.$ at $281.0 \mathrm{eV}$ and $\mathrm{Ru}^{4+}$ at $\left.283.3 \mathrm{eV}\right)$ except $\mathrm{Ru}$ species on bentonite shows chemical state of $\mathrm{Ru}^{0}$ species only. Previous study have found that B.E of $\approx 283.0 \mathrm{eV}$ was assigned to $\mathrm{RuO}_{2}$ which is corresponding to $\mathrm{Ru}^{4+}$ species. ${ }^{9}$ Meanwhile according to [3] the B.E value of $\mathrm{Ru}^{0}$ species was in the range $280-281 \mathrm{eV} .{ }^{9}$ The presence of $\mathrm{Ru}^{4+}$ species indicated the $\mathrm{Ru}$ exists as oxide form and this species might be form during calcinations process. 


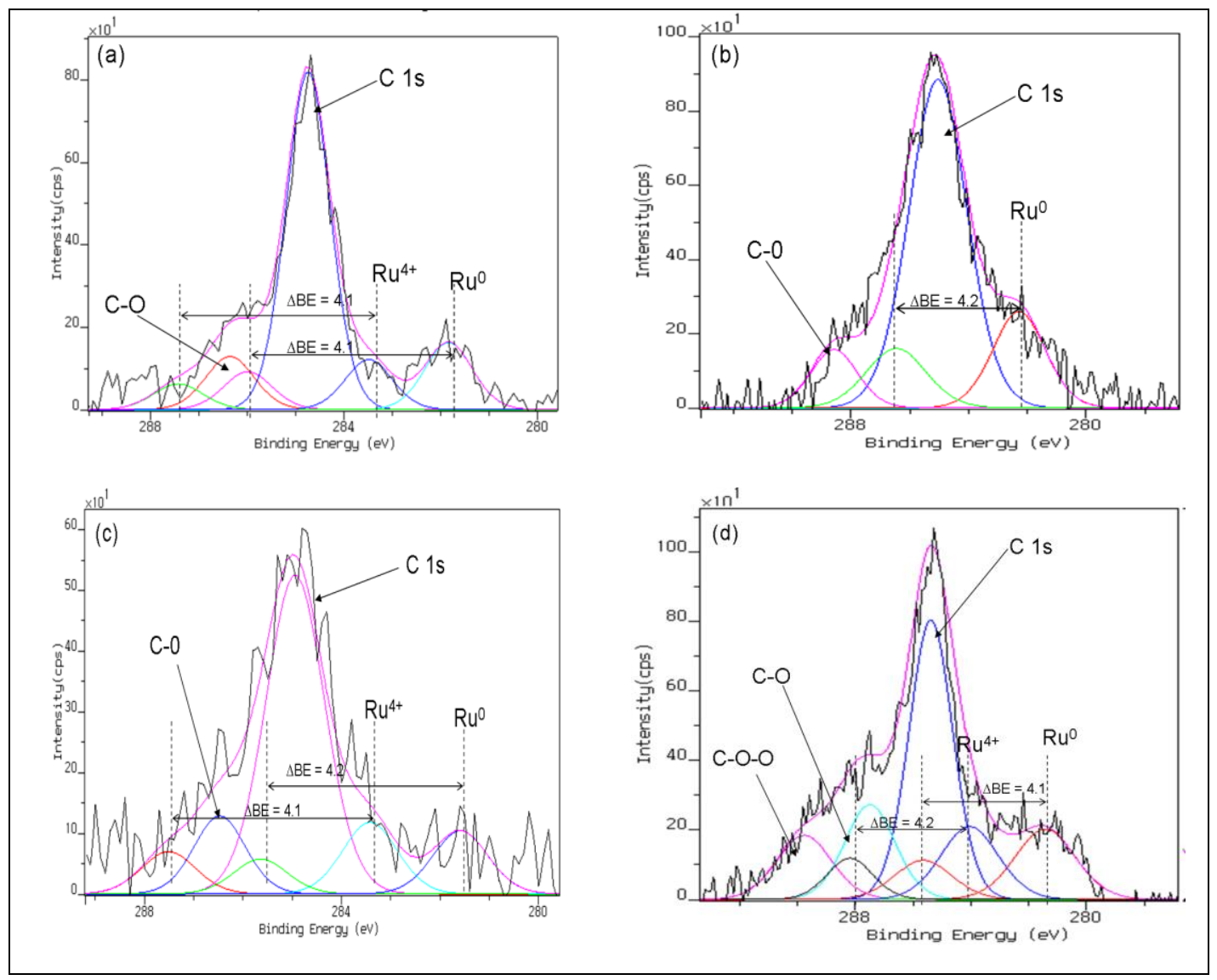

Figure 2. XPS narrow scan of $\mathrm{Ru} 3 \mathrm{~d}_{5 / 2}$ for (a) $\mathrm{Ru} / \mathrm{Al}_{2} \mathrm{O}_{3}$, (b) Ru/bentonite, (c) $\mathrm{Ru} / \mathrm{TiO}_{2}$ and (d) $\mathrm{Ru} / \mathrm{SiO}_{2}$

Figure 3 present the morphology of the catalyst analyze by TEM and the average size particle measured by TEM of $\mathrm{Ru}$ particle on bentonite, $\mathrm{Al}_{2} \mathrm{O}_{3}, \mathrm{SiO}_{2}$ and $\mathrm{TiO}_{2}$ obtained were $\approx 1.5 \mathrm{~nm},<2 \mathrm{~nm}, \approx 2 \mathrm{~nm}$ and 4-6 nm. This result indicate that particles size of $\mathrm{Ru}$ were much smaller on bentonite support than others support and activity of $\mathrm{Ru} /$ bentonite was expected was much higher than others catalyst in hydrogenolysis glycerol.

\section{Glycerol hydrogenolysis reaction}

The effect of support materials on catalytic of behavior of Ru catalyst for hydrogenolysis glycerol was investigated under mild reaction condition of $150{ }^{\circ} \mathrm{C}, 20$ bar initial hydrogen pressure for 7 hours reaction time. The concentration of aqueous glycerol and catalyst loading used in this study are $20 \%$ (wt) and $5 \%$ respectively. The order of Ru catalyst activity was $\mathrm{Ru} /$ bentonite $>\mathrm{Ru} / \mathrm{Al}_{2} \mathrm{O}_{3} \approx \mathrm{Ru} / \mathrm{TiO}_{2}>\mathrm{Ru} / \mathrm{SiO}_{2}$. Figure 4 shows that $\mathrm{Ru} /$ bentonite catalyst was the most active catalyst which gave glycerol conversion reached $62.8 \%$. Good catalytic of $\mathrm{Ru} /$ bentonite is supported by TEM analysis since the average particle Ru/bentonite obtained was the smallest among the catalyst studied. Previous study reported that activity of Ru based catalyst was most active on smaller particle size of $\mathrm{Ru}^{2}$ Mapping analysis by FESEM showed that dispersion of Ru particle was also related to the catalytic activity of $\mathrm{Ru}$ catalyst. Ru/bentonite which is most active was relatively more dispersed on bentonite support compared to other support. This result indicates that bentonite which has basic property support gave high conversion compared to acidic support $\left(\mathrm{SiO}_{2}, \mathrm{Al}_{2} \mathrm{O}_{3}\right.$ and $\left.\mathrm{TiO}_{2}\right)$. Interestingly, $\mathrm{Ru}$ /bentonite also gave high selectivity to 1,2-propanediol (80.1\%) compared to other catalysts which are support on $\mathrm{TiO}_{2}, \mathrm{SiO}_{2}$ and $\mathrm{Al}_{2} \mathrm{O}_{3}$. 

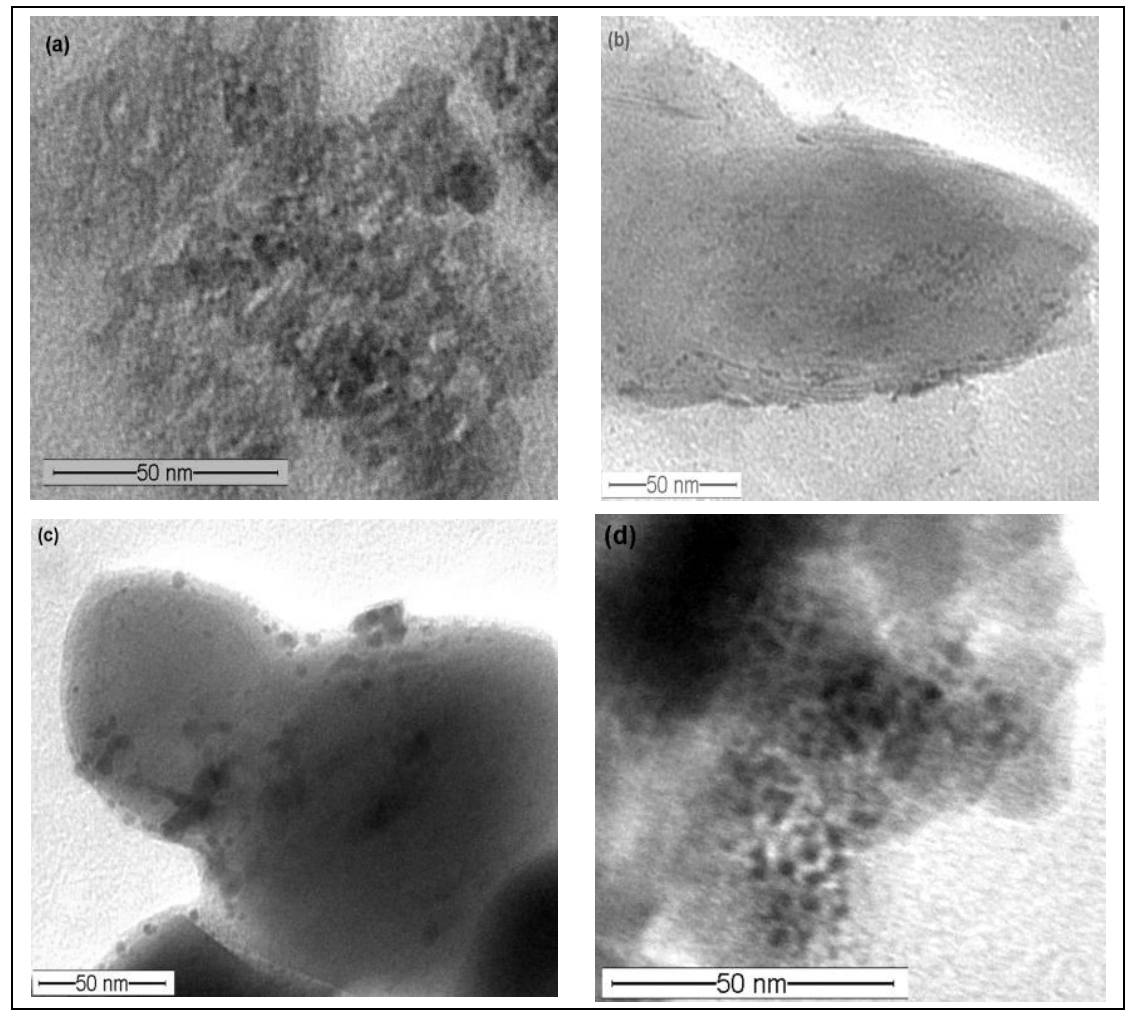

Figure 3. TEM image of (a) $\mathrm{Ru} / \mathrm{Al}_{2} \mathrm{O}_{3}$, (b) Ru/Bentonite, (c) $\mathrm{Ru} / \mathrm{TiO}$, and (d) $\mathrm{Ru} / \mathrm{SiO}_{2}$

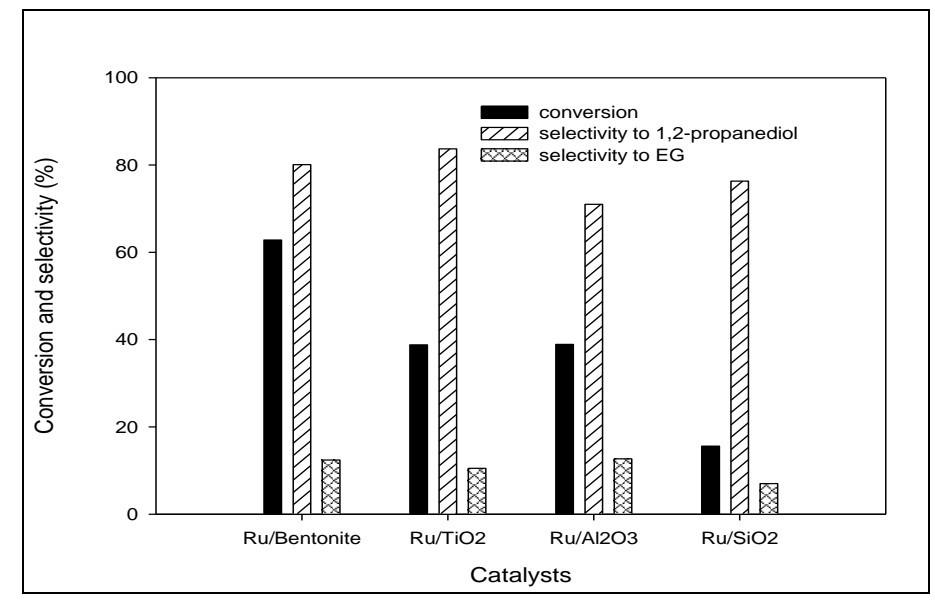

Figure 4. Hydrogenolysis glycerol over Ru-based catalyst at different support

Furthermore, XPS analysis showed that $\mathrm{RuO}_{2}$ species was reduced to $\mathrm{Ru}^{0}$ species completely on bentonite compared to other supports. This result indicates that $\mathrm{Ru}^{0}$ species was the active species that contributes the best 
performance of Ru/bentonite catalyst. Surface area of Ru/bentonite analyzed by BET shows moderate BET surface area $\left(35.4 \mathrm{~m}^{2} / \mathrm{g}\right)$ compared to $\mathrm{Ru} / \mathrm{SiO}_{2}\left(131.0 \mathrm{~m}^{2} / \mathrm{g}\right)$ and $\mathrm{Ru} / \mathrm{Al}_{2} \mathrm{O}_{3}(141.0)$. However this does not indicate that the catalyst is not good for hydrogenolysis reaction because BET surface area is not the only factor that contributes to good catalytic activity of the catalyst. Other factors such as types and shapes of pore need to be considered [9].

From the catalytic result, there is a correlation between the types of pores with the activity of the catalyst. The catalyst with Type H2 (non-uniformed cylindrical pore) gave pores which have good catalytic activity with $62.8 \%$ conversion. The other catalysts with Type H4 (non-uniformed slit shaped) gave only around 10-35\% conversion. As such we can assume that cylindrical pore is an ideal pore shape for hydrogenolysis glycerol reaction. This is because the adsorption and desorption process can easy to takes place in cyclindrical pore during hydrogenolysis glycerol.

\section{Conclusion}

It was found that the nature of support material greatly influence the performance of the supported Ru catalyst. A bentonite suppored $\mathrm{Ru}$ catalyst (Ru/bentonite) exhibited the predominant activity and selectivity among the test catalyst and in a base-free aqueous solution under lower pressure. To best of our knowledge, $\mathrm{Ru} /$ bentonite system catalyst has not been reported yet for hydrogenolysis glycerol. Further study on the acidity and basicity of support has to be carried out.

\section{Acknowledgement}

The authors would like to acknowledge the Research Management Institute (RMI), Universtiti Teknologi MARA (UiTM) to finance the project under the FRGS Fund (FRGS/1/2014/STA01/UiTM/02/04).

\section{References}

1. Maris, E. P. and Davis, R. J. (2007). Hydrogenolysis of glycerol over carbon-supported Ru and Pt catalysts. Journal of Catalysis, 249(2): 328 - 337.

2. Bolado, S., Treviño, R. E., García-Cubero, M. T., and Benito, G. G. (2010). Glycerol hydrogenolysis to 1, 2 propanediol over Ru/C catalyst. Catalysis Communications, 12(2): 122 - 126.

3. Balaraju, M., Rekha, V., Prasad, P. S. S., Devi, B. L. A. P., Prasad R. B. N. and Lingaiah N. (2009). Influence of solid acids as co-catalysts on glycerol hydrogenolysis to propylene glycol over Ru/C catalysts. Applied Catalysis A: General, 354(1-2): 82 - 87.

4. Balaraju, M., Rekha, V., Sai Prasad P. S., Prasad R. B. N. and Lingaiah N. (2008). Selective hydrogenolysis of glycerol to 1, 2 propanediol over $\mathrm{Cu}-\mathrm{ZnO}$ catalysts. Catalysis Letters, 126(1): 119 - 124.

5. Vasiliadou, E. S., Heracleous, E., Vasalos I. A., and Lemonidou A. A. (2009). Ru-based catalysts for glycerol hydrogenolysis - effect of support and metal precursor. Applied Catalysis B: Environmental, 92(1-2): 90-99.

6. Maris, E. P., Ketchie, W. C., Murayama M. and Davis R. J. (2007). Glycerol hydrogenolysis on carbonsupported $\mathrm{Pt} / \mathrm{Ru}$ and $\mathrm{Au} / \mathrm{Ru}$ bimetallic catalysts. Journal of Catalysis, 251(2): 281- 294.

7. Nakagawa, Y., Shinmi, Y., Koso S. and Tomishige K. (2010). Direct hydrogenolysis of glycerol into 1,3propanediol over rhenium-modified iridium catalyst. Journal of Catalysis, 272(2):191 - 194

8. Huang, L., Zhu, Y., Zheng, H., Ding, G. and Yongwang, Li. (2009). Direct conversion of glycerol into 1,3propanediol over $\mathrm{Cu}-\mathrm{H}_{4} \mathrm{SiW}_{12} \mathrm{O}_{40} / \mathrm{SiO}_{2}$ in Vapor Phase. Chemistry Letters, 131(1):312 - 320.

9. Feng, J., Fu. H., Wang, J., Li, R., Chen, H. and Li, X. (2008). Hydrogenolysis of glycerol to glycols over ruthenium catalysts: Effect of support and catalyst reduction temperature. Catalysis Communications, 9(6): $1458-1464$.

10. Zhou, Z., Li, X. Zeng, T., Hong, W., Cheng Z. and Yuan, W. (2010). Kinetics of Hydrogenolysis of Glycerol to Propylene Glycol over Cu-ZnO- $\mathrm{A}_{12} \mathrm{O}_{3}$ Catalysts. Chinese Journal of Chemical Engineering, 18(3): 384 - 390.

11. Shinmi, Y., Koso, S., Kubota, T., Nakagawa. Y. and Tomishige, K. (2010). Modification of $\mathrm{Rh} / \mathrm{SiO}_{2}$ catalyst for the hydrogenolysis of glycerol in water. Applied Catalysis B: Environmental, 94(3-4): 318 - 326.

12. Miyazawa, T., Koso, S., Kunimori, K. and Tomishige, K. (2007). Glycerol hydrogenolysis to 1,2-propanediol catalyzed by a heat-resistant ion-exchange resin combined with Ru/C. Applied Catalysis A: General, 329: 30 35 .

13. Jiang, T., Zhou, Y., Liang, S., Liu H. and Han B. (2009) Improved utilisation of renewable resources: New important derivatives of glycerol. Green Chemistry, 7: 1000 - 1006. 
14. Yuan, Z. Wang, J., Wang, L., Xie, W., Chen, P., Hou Z. and Zheng. X., (2010). Biodiesel derived glycerol hydrogenolysis to 1,2-propanediol on $\mathrm{Cu} / \mathrm{MgO}$ catalysts. Bioresource Technology, 101: $7088-7092$.

15. Balaraju, M., Rekha, V., Devi, B. L. A. P., Prasad, R. B. N., Prasad P. S. S. and Lingaiah N. (2010). Surface and structural properties of titania-supported Ru catalysts for hydrogenolysis of glycerol. Applied Catalysis A: General 384: 107 - 114. 